\title{
Application of Learned Optimism and Mindful Parenting for Caregivers of Putra Utama 03 Ceger Orphanage
}

\author{
Yohana Ratrin Hestyanti ${ }^{1 *}$ \\ ${ }^{1}$ Faculty of Psychology \\ Universitas Katolik Atma Jaya, Jakarta, Indonesia \\ yohana.hestyanti@atmajaya.ac.id \\ Penny Handayani ${ }^{2}$, Abriyanti Riyanti ${ }^{3}$, Sylvidire Maharani ${ }^{4}$, Nelson Zelig ${ }^{5}$, Alyssa Abidin ${ }^{6}$, \\ Tjong Michaella ${ }^{7}$, Stephanie Anggun ${ }^{8}$ \\ 2,3,4,5,6,7,8 Faculty of Psychology \\ Universitas Katolik Atma Jaya, Jakarta, Indonesia \\ penny.handayani@atmajaya.ac.id, rabriyani@yahoo.com, sylvidire@gmail.com, \\ nelsonzelig@gmail,com, alyssaabidin@gmail.com, tjongmichaella@gmail.com, \\ tephanieanggun@gmail.com
}

(Received January 31, 2021, accepted March 09, 2021)

\begin{abstract}
There used to be a gap between ideal and actual condition in the pattern of parenting at Panti Sosial Asuhan Anak (PSAA) Putra Utama 03 Ceger, an orphanage. The gap was caused by some factors namely the environment facilities, high levels of problematic behavior among adolescents, the system, insufficient number of caregivers, and cultural factors of parenting that have been going on for a long time in the orphanage. The gap could lead to learned helplessness of the caregivers in parenting pattern on children at the orphanage. A team was formed to create an intervention through community service activity to overcome the problem, by applying learned optimism and mindful parenting for the caregivers at the orphanage. This intervention program was aimed to increase the caregiver's knowledge and motivation through training of learned optimism and mindful parenting. Therefore, the caregivers can be more optimistic and wholehearted in carrying out their role as caregivers. The approach used in this intervention is based on the Bioecological Model Theory from Bronfenbrenner, the Experiential Learning from Bandura, and the Change Theory by Lewin. The steps taken in this intervention program were a preliminary study using a problem tree, Fishbone Analysis, and SWOT analysis. After a preliminary study, the team prepared an intervention design consisting of preparation, training, monitoring, and evaluation of the intervention. The expected targets of this intervention program were an increasing knowledge in learned optimism training and caregivers' motivation in applying the training materials. These indicators have been achieved well through the activities provided.
\end{abstract}

Keywords: learned helplessness; learned optimism; mindful parenting; orphanage 


\section{Introduction}

Lembaga Kesejahteraan Sosial Anak (LKSA) or institution-based child welfare service is expected to be the last alternative in children care. In Indonesia, since 2011, the term LKSA is a change from the previous name, the Panti Sosial Asuhan Anak (PSAA) or social institution for children care. The institution has an obligation to provide a substitute role for parents for foster children as an alternative caregiver. Caregivers are people who have the duty to care for foster children, or who are called temporary to substitute parental role.

Panti Sosial Asuhan Anak Putra Utama 03 (orphanage) is one of the LKSA-based care services. The orphanage has two branches, one of which is PSAA Putra Utama 03 Ceger branch, East Jakarta. This branch specializes in taking care of boys with age range of 12 to 19 years old, totaling 81 children. Workers in the orphanage consist of Pekerja Sosial (PekSos) or social workers, Pegawai Negeri Sipil (PNS) or civil servants, and security guards. Caregivers are orphanage workers who have a higher intensity of face-to-face interaction with foster children than other workers because they have high responsibilities and demands in fulfilling the various needs of the children. The caregivers themselves consist of PekSos and PNS, with a total number of 25 people.

In accordance with the care standards for LKSA, caregivers have a role in fulfilling and protecting children's rights in accordance with Law No. 23 of 2002. This means that caregivers have the responsibility to ensure the growth and development of children physically, mentally,

spiritually, and socially. In the end, all these efforts are aimed to support foster children in becoming capable and responsible adults, both for themselves and for the society (Napitupulu, Nashori, \& Kurniawan, 2007). This standard of care applies to all LKSAs, including PSAA Putra Utama 03 Ceger.

In practice, implementing this standard of care is not easy. Especially with the various growth and development challenges experienced by foster children. The age range of 12 to 19 for foster children of PSAA Putra Utama 03 Ceger, which is the period of adolescent development. According to Dryfoos and Barkin (Santrock, 2014), the teenage phase has its own challenges. The process of searching for identity in adolescence sometimes leads adolescents into behavioral problems, such as juvenile delinquency. 
Behavioral problems in adolescence are closely related to family parenting factors or caregivers. Based on Sobotkova (Santrock, 2014), parenting style plays an important role in adolescent behavior and how they behave in their surroundings. Poor parenting is reflected in the low monitoring of children, low closeness and emotional support between caregivers and children, and low application of discipline. Meanwhile, a warm and supportive environment can be realized by fulfilling one's love and belongingness needs (Baumeister \& Leary, 1995). (Santrock, 2014) also states that adolescents need a warm and supportive family environment to be able to develop optimally during their development. When linked back to adolescent development, this need for love and ownership is related to Maslow's hierarchy of needs, which places these two elements as the third layer of the five development needs of an adolescent so that it can lead to a positive self.

In practice associated with Maslow's theory of needs, the caregivers of PSAA Putra Utama 03 have met the basic needs of foster children in the first and second layers, namely physiological and safety needs. Fulfilling the needs of food, clothing, shelter, and security for the institution are examples of its application. But unfortunately, it is love and a sense of belonging which are the third layer of need that is challenging to do. The implementation of the fulfillment of the care needs from the caregivers to the children are experiencing obstacles due to the insufficient number of caregivers to have an intensive and quality relationship with the number of existing foster children.

The conditions described above explain that adolescent behavioral problems that continue to occur can be caused by a lack of ownership and fulfillment of children's affection with their immediate environment, namely the caregivers of the orphanage. In fact, in practice, caregivers also feel they have many demands in carrying out their daily duties. Not only raising children, but they also have to do some administrative tasks at the orphanage and have to live their own lives. The large number of administrative duties and adolescent behavioral problems that continue to occur can cause the caregivers themselves to feel tired in carrying out their main duties, caring for the orphanage. In the end, the fatigue experienced by the caregivers causes the entire phenomenon to become a cycle as if there is no way out.

Several intervention programs carried out by psychologists who work at the orphanage have been carried out to overcome existing adolescent behavioral problems, namely by providing soft skills training and knowledge that can be applied in the children's live, with expected 
quality individual development. Meanwhile, programs given to the caregivers as the children counterpart have never been carried out, even though the caregivers also experience fatigue and hopelessness in caring for orphanages. The actual condition that occurs is that even though several intervention programs have been given, the problem of the orphanage adolescent behavior still occurs. In this case, it can be explained based on Bronfrenbrenner theory (Senefeld \& Perrin, 2014), where the immediate environment has a major influence on the development of the individual. In PSAA Putra Utama 03, the closest environment to the children in the orphanage in question is the caregivers. The improvement of the environmental system should be carried out in a balanced manner so that it can result in a process of a reciprocal relationship between the children and the immediate environment, namely the caregivers. In addition, the relationship process that occurs is reciprocal, so that in the end if one party experiences changes (either positive or negative), then the other party from the same environment can be affected.

The gap between the ideal conditions and the actual conditions in the orphanage has made the community service team intrigued to improve these conditions and seeking for a change. Changes can be made by providing intervention towards the main problem from the phenomena, namely the condition of caregivers who experience fatigue in carrying out the role of caring, hence, they lack the motivation to provide optimal care.

In order to tackle this condition, the intervention program aimed to increase caregivers knowledge of optimistic thinking and to give information on how caregivers can apply simple methods that may help them become calmer when facing obstacles in caring for orphanage children. This intervention is based on a learned theory of optimism and mindful parenting. The target of this learning process is mostly the cognitive and affective sides of the participants. Therefore, participants can see problems from a more positive side and are not only shackled to negative situations. In addition, participants are expected to be more motivated to implement a number of alternatives in childcare, so they can be more sincere and wholehearted in showing affection for the children.

Mindful parenting is a parenting process that involves the best possible awareness and attention at every opportunity. This includes becoming aware of things that are on the inside. Thoughts, emotions, and sensations felt by the body (Bogels \& Restifo, 2014). Meanwhile, learned optimism is an adaptive attribution to explain negative events that happen to them. Optimists 
explain bad things in the following way; 1) taking into account the role of other people and the environment when getting a bad result (external attribution), 2) interpreting a bad event as something that will never happen again (variable attribution), 3) requiring this bad result to only occur in one area and does not in other fields (specific attribution) (Carver \& Scheier, 1999).

\section{Methods}

\section{Intervention Participants}

In this community service activity, the main target was the orphanage workers who interact directly with children, such as caregivers. Caregivers who work in the orphanage are workers who directly interact and are responsible for their foster children. Because of on duty participants in caring for children that prevented some participants from being able to participate in the whole training activities, made the group of participants involved in this activity different for each day. On the first day there were 14 people, on the second day there were 14 people and on the third day there were 11 people.

\section{Implementation of Interventions \\ Preparatory Procedure}

This community service activity used literature study and interview methods to explore the phenomena. Interviews were conducted with people who work in the orphanage. Based on interviews and literature studies, problems were able to be found and then the problem would be intervened and the objectives and indicators of success of the intervention were determined. Based on the results of the needs analysis, this activity aimed to help the caregivers of the orphanage at PSAA Putra Utama 03, Ceger to be more optimistic and mindful in carrying out their role as caregivers.

There were two indicators of success as benchmarks for achieving activity objectives. First, there was an increase in knowledge about training materials (learned optimism and mindful parenting). This indicator targets the understanding of the material provided during the training. Second, there was an increase in the caregivers motivation in applying the training materials in caring for the children. The objective was to help the caregivers of the orphanage at PSSA Putra Utama 03, Ceger so they can be more optimistic and wholeheartedly in carrying out their role as caregivers and can be measured by knowing caregivers motivation. Additionally, to 
support the motivation indicator, there was an additional indicator needed. This indicator measured change in perspective on caregivers self-abilities and expectations in achieving the caregiving targets. This way of looking at one's own abilities is important because this is one of the characteristics of an optimistic person.

\section{Implementation Procedure}

The intervention provided was in the form of an activity program in the form of training entitled "The Golden Ways Training" with the material consist of learned optimism and mindful parenting. The training was conducted for three days from 21-23 November 2017 at the 03 Ceger Social Orphanage, East Jakarta. The duration of training was three to four hours per day. The training instrument used was the pre-test and post-test sheets each for the caregiver expectation form, and a motivation questionnaire form, namely the Parent Motivation Inventory (PMI).

There were specific objectives and a different set of activities on these three days of training. On the first day, the specific objective of the training was to assist the orphanage caregivers in preparing themselves for the entire training series. The activities carried out on the first day were activities that can help the caregivers of the orphanage to release fatigue from the routine at the orphanage, becoming more aware of their own emotions, and providing help while doing their duties as caregivers. On the second day, the specific aim of the training was to help the orphanage caregivers to be more optimistic. The activity given was an explanation of the material about learned optimism and applying $\mathrm{ABC}$ (Affective, Behavior, and Cognitive) Model. On the third day, the specific objective of the training was to help the orphanage caregivers to be more mindful in carrying out their role as caregivers. The activity given was an explanation of the mindful parenting material.

Activity instruments were given during the training session and after the training ends. On the first and third day of training, each of the caregivers were given an expectation sheet to fill in their personal expectations. Expectation sheets were given on the first and last day in order to understand the changes in the caregivers' self-goal expectation. On the second and third day of the training, the team provided pre-tests and post-tests to measure the orphanage caregivers knowledge regarding the material learned about optimism and mindful parenting. On December 7, 2017, the team provided a Parent Motivation Inventory (PMI) questionnaire by 
(Nock \& Photos, 2006) to see the motivation of caregivers in applying parenting materials in training.

This activity used four ways to support the sustainability of the intervention. The first was to provide workbooks to orphanages. The training workbook contains an explanation of the material presented and a place to apply the theory. The second was the integrity pact by the caregivers of the orphanage. The third was the provision of several posters containing the core discussion of the theories presented during the training. The fourth was a training recommendation to PSAA Putra Utama 03, Ceger.

\section{Data Analysis Method}

This activity used a one-group pretest-posttest design to measure increased knowledge about training materials. The results of the two tests were processed by using a nonparametric statistical analysis test method, Wilcoxon signed-rank test. This activity also used the coding method in processing data for qualitative analysis methods on the caregivers expectation sheets. Coding was divided into three major parts, namely expectations for themselves, expectations for the orphanage children, and expectations for orphanage colleagues.

The level of motivation in applying training materials to parenting was measured by the parent motivation scale of inventory. The PMI is a self-report measure of 25 items of parental motivation on a five-point scale $(1=$ strongly disagree; $5=$ strongly agree). The resulting items correspond to the three main components of motivation, namely the desire to change children's attitudes, readiness to change behavior in parenting, and feel the ability to change parenting behavior (Nock \& Photos, 2006). The higher the score obtained by the respondent, the higher the motivation in applying the training material in parenting, on the other hand, the lower the score obtained by the respondent indicates the lower the motivation in applying the training material in parenting.

\section{Results and Discussions}

\section{Quantitative Results}

Measurements in this activity included pre-test and post-test, each measured twice according to the material provided, then followed by a measurement of motivation to the subject, namely the orphanage caregivers. The pre-test measurements were taken at the beginning of the 
training on the day it started and the post-test measurements were taken after the training. These measurement results can be seen in Table 1 to Table 6 .

Table 1. Score of Subject Knowledge Against the Learned Optimism Material on the Second Day of Training Prates, Posttests, and Gained Score

\begin{tabular}{cccc}
\hline & & Measurement & \\
\cline { 2 - 4 } Subject & Pre-test & Post-test & Gained Score \\
\hline GS & 7 & 9 & 2 \\
\hline U & 3 & 7 & 4 \\
\hline A & 6 & 9 & 3 \\
\hline KK & 4 & 10 & 6 \\
\hline R & 6 & 10 & 4 \\
\hline SM & 5 & 7 & 2 \\
\hline I & 6 & 6 & 0 \\
\hline W & 4 & 5 & 1 \\
\hline AM & 4 & 9 & 5 \\
\hline NA & 6 & 10 & 3 \\
\hline DY & 7 & 10 & 3 \\
\hline AT & 7 & 10 & 2 \\
\hline G & 7 & 9 & 2 \\
\hline F & 6 & 8 & 2.93 \\
\hline Mean (Total/n) & 5.57 & 8.50 & \\
\hline
\end{tabular}

Tabel 2. Descriptive Statistics of Day 2 Training Subjects

\begin{tabular}{llcccc}
\hline Group & N & Min & Max & Mean & SD \\
\hline Pre-test & 14 & 3 & 7 & 5.57 & 1.34 \\
\hline Post-test & 14 & 5 & 10 & 8.50 & 1.65 \\
\hline Gained Score & 14 & 0 & 6 & 2.93 & 1.59 \\
\hline
\end{tabular}


Tabel 3. Score of Subject Knowledge Against Mindful Parenting Material on the Levels, Posttests, and Gained Score of Training Day 3

\begin{tabular}{cccc}
\hline & & Measurement & \\
\cline { 2 - 4 } Subject & Pre-test & Post-test & Gained Score \\
\hline NA & 3 & 6 & 3 \\
\hline S & 4 & 7 & 3 \\
\hline F & 3 & 4 & 1 \\
\hline W & 3 & 3 & 0 \\
\hline T & 5 & 6 & 1 \\
\hline DY & 6 & 9 & 3 \\
\hline A & 3 & 5 & 2 \\
\hline KK & 3 & 8 & 5 \\
\hline R & 4 & 7 & 3 \\
\hline RS & 2 & 4 & 2 \\
\hline AM & 5 & 7 & 2 \\
\hline Mean (Total/n) & 3.73 & 6.00 & 2.27 \\
\hline
\end{tabular}

Tabel 4. Descriptive Statistics of Day 3 Training Subjects

\begin{tabular}{llcccc}
\hline \multicolumn{1}{c}{ Group } & N & Min & Max & Mean & SD \\
\hline Pre-test & 11 & 2 & 6 & 3.73 & 1.19 \\
Post-test & 11 & 3 & 9 & 6.00 & 1.84 \\
Gained Score & 11 & 0 & 5 & 2.27 & 1.35 \\
\hline
\end{tabular}

Tabel 5. Wilcoxon Signed Ranks Test on the Results of Measurement of Subject : Pre-test and Post-test

\begin{tabular}{llccc}
\hline & N & $\begin{array}{c}\text { Mean } \\
\text { Rank }\end{array}$ & $\begin{array}{c}\text { Sum of } \\
\text { Ranks }\end{array}$ \\
\hline Postes2 - Prates2 & Negative Ranks & $0^{\mathrm{a}}$ & 0.00 & 0.00 \\
& Positive Ranks & $13^{\mathrm{b}}$ & 7.00 & 91.00 \\
& Ties & $1^{\mathrm{c}}$ & & \\
& Total & 14 & & \\
\hline Postes3 - Prates3 & Negative Ranks & $0^{\mathrm{d}}$ & 0.00 & 0.00 \\
& Positive Ranks & $10^{\mathrm{e}}$ & 5.50 & 55.00 \\
& Ties & $1^{\mathrm{r}}$ & & \\
& Total & 11 & & \\
\hline a. Postes2 < Prates2 & & & & \\
b. Postes2 > Prates2 & & & & \\
c. Postes2 = Prates2 & & & & \\
d. Postes3 < Prates3 & & & & \\
e. Postes3 > Prates3 & & & & \\
f. Postes3 = Prates3 & &
\end{tabular}


Tabel 6. Wilcoxon Signed Ranks Test on the Results of Measurement of Subject Pre-test and Post-test

\begin{tabular}{lr|r}
\hline & $\begin{array}{r}\text { Postes2 - } \\
\text { Prates2 }\end{array}$ & $\begin{array}{c}\text { Postes3 - } \\
\text { Prates3 }\end{array}$ \\
\hline Z & $-3.197^{\mathrm{b}}$ & $-2.831^{\mathrm{b}}$ \\
Asymp. Sig. (2-tailed) & 0.001 & 0.005 \\
\hline a. Wilcoxon Signed Ranks Test \\
b. Based on negative ranks.
\end{tabular}

The results obtained from the entire pre-test and post-test were processed using the Wilcoxon signed ranks test. Wilcoxon signed ranks test $(T=0, n=14, p<0.05)$ indicated that the second day of training "The Golden Ways" significantly affected participants knowledge of learned optimism (pre-test2-posttest2) positively. The number of positive difference ranks $\left(\sum \mathrm{R}+=13\right)$ was greater than the number of negative difference ranks $(\Sigma \mathrm{R}-=0)$, indicating a positive impact of training. Wilcoxon signed ranks test $(T=0, n=11, p<0.05)$ indicated that the 3rd day of "The Golden Ways" training significantly affected participants knowledge of mindful parenting (pre-test3-post-test3) positively. The number of positive difference ranks $\left(\sum \mathrm{R}+=\right.$ 10) was greater than the number of negative difference ranks $(\Sigma \mathrm{R}-=0)$, indicating a positive impact from training.

The two results of processed data showed a significant positive impact on the subject knowledge of the material provided in the training. This indicated that the objectives of the activity have been achieved, namely an increase in knowledge about training materials (learned optimism and mindfulness parenting). The results of motivation measurements carried out 15 days after the implementation of the training are presented in Table 7.

Measurement of caregivers motivation in applying training materials indicated high motivation (30.77\% answered agree and $69.23 \%$ answered strongly agree). This showed the achievement of the goals, namely the motivation of the caregivers in applying the training materials. 
Tabel 7. Results of Measurement of Carer Motivation in Implementing Training Materials

\begin{tabular}{ccccc}
\hline Item Number & Mean & SD & \% Agree & \% Strongly Agree \\
\hline 1 & 3.71 & 0.47 & 30.77 & 69.23 \\
\hline 2 & 3.57 & 0.51 & 46.15 & 53.85 \\
\hline 3 & 3.79 & 0.43 & 23.08 & 76.92 \\
\hline 4 & 3.93 & 0.27 & 7.69 & 92.31 \\
\hline 5 & 3.71 & 0.47 & 30.77 & 69.23 \\
\hline 6 & 3.86 & 0.36 & 15.38 & 84.62 \\
\hline 7 & 3.57 & 0.51 & 46.15 & 53.85 \\
\hline 8 & 3.57 & 0.51 & 38.46 & 61.54 \\
\hline 9 & 3.57 & 0.51 & 46.15 & 53.85 \\
\hline 10 & 3.79 & 0.43 & 23.08 & 76.92 \\
\hline 11 & 3.71 & 0.47 & 30.77 & 69.23 \\
\hline 12 & 3.50 & 0.52 & 46.15 & 53.85 \\
\hline 13 & 3.71 & 0.47 & 30.77 & 69.23 \\
\hline 14 & 3.79 & 0.43 & 15.38 & 84.62 \\
\hline 15 & 3.71 & 0.47 & 23.08 & 76.92 \\
\hline 16 & 3.64 & 0.50 & 38.46 & 61.54 \\
\hline 17 & 3.64 & 0.50 & 38.46 & 61.54 \\
\hline 18 & 3.79 & 0.43 & 23.08 & 76.92 \\
\hline Average & 3.70 & 0.46 & 30.77 & 69.23 \\
\hline
\end{tabular}

\section{Additional Results}

On the first and third days, the team used the "expectation sheet" to see changes in the caregivers' self-goal expectations. The following is the result of the hope sheet provided.

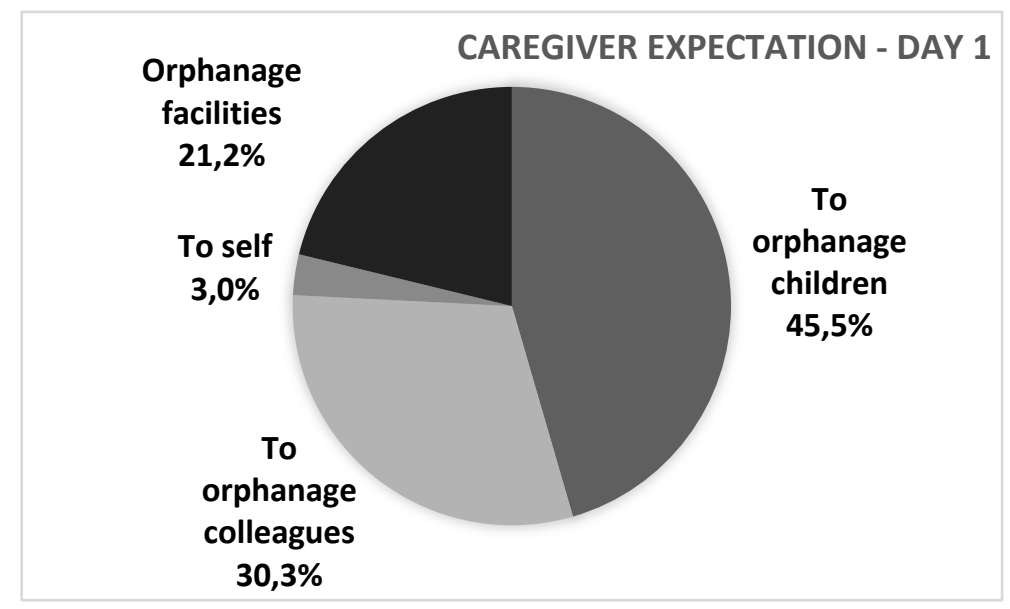

Fig. 1. Subject's Initial expectations 


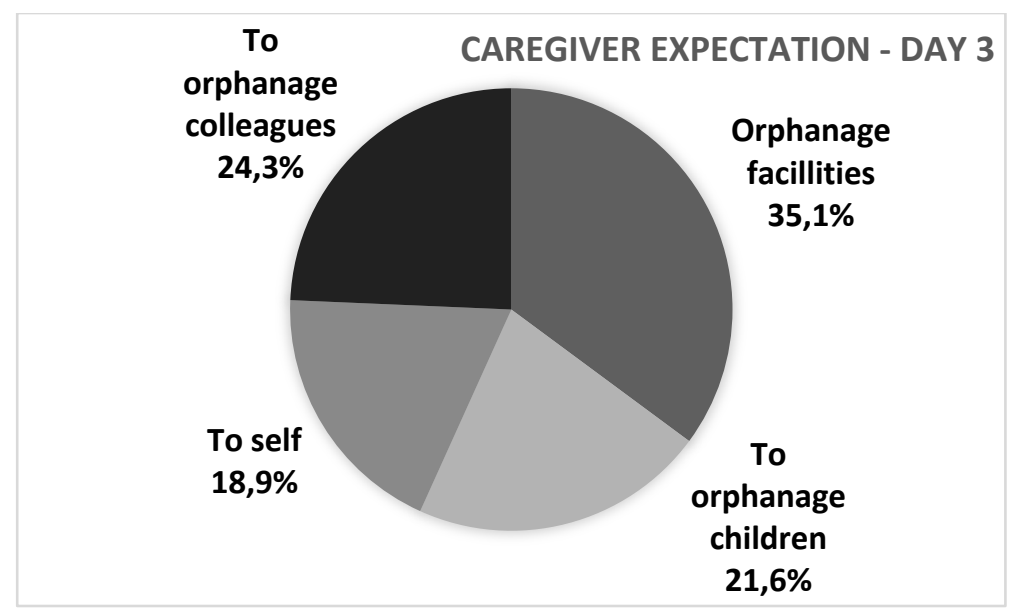

Fig. 2. Subject's Final expectations

From the two diagrams above, it can be seen that on the first day of training the participants expectations of themselves had a small percentage which means that they did not show an optimistic attitude. However, on the third day after the participants received material on learned optimism, there was a higher percentage of self-goal expectation compared to the previous two days. This shows that the target of the activity has been achieved, that is, there was a change in the caregiver's self-goal expectation.

\section{Discussions}

From the results, we can see that the two indicators and one additional indicator have been achieved by the activities provided. This shows that the measurement used to determine the achievement of the targets was precise. Training as one of its methods was able to increase knowledge about the material provided (learned optimism and mindful parenting), improve on how to view one's abilities and expectations in achieving caregiving targets, and increase motivation to apply the principles obtained from training in parenting that they will do.

During the training, the team found several problems that needed to be addressed to enable the caregivers to carry out their duties for the orphanage children optimally. The first problem the team found was that caregivers had other burdens beyond their burden as caregivers. This problem was discovered by the team in a sharing session conducted in training. Many caregivers confided about their burdens outside the orphanage matters. The team felt that these two problems were also factors causing the gap between the ideal conditions and the actual conditions of caregivers at PSAA Putra Utama 03 Ceger. 
This activity also has limitations such that the implementation in this community service activity was less than ideal. The main limitation experienced by the team was the limited time in conducting training and seeing the results of the training carried out. The implementation of training on mindful parenting is considered to have limitations because it took eight weeks to practice the application of mindful parenting and the ideal duration for each session is three hours (Bogels \& Restifo, 2014), while the team only had three days to carry out the entire series of activities. The time limitation experienced by the team in seeing the training results was when the team wanted to see an increase in the motivation of the orphanage caregivers after attending the training. According to Lally, Van Jaarsveld, Poots, and Wardle (2009), the time span needed by a person to implement a new habit in their daily life is 18 to 254 days, whereas, in this training, the team only had 15 days to measure the increase in motivation of the caregivers after attending the training.

The time limitation caused the delivery of material to be not optimal. Mindful parenting training from (Bogels \& Restifo, 2014) includes eight sessions that contain many reflective activities because they make the participants affective side the main target of the training. But because of time limitation, the team only included three out of eight sessions. The reflective activities were also limited because in one day the training was not effective if three reflective activities were carried out.

The discussion on learned optimism material was also limited by time. At the time of preparation, this training material was prepared by considering a lot of applicative discussion of the material, but it could not be done because of limited time.

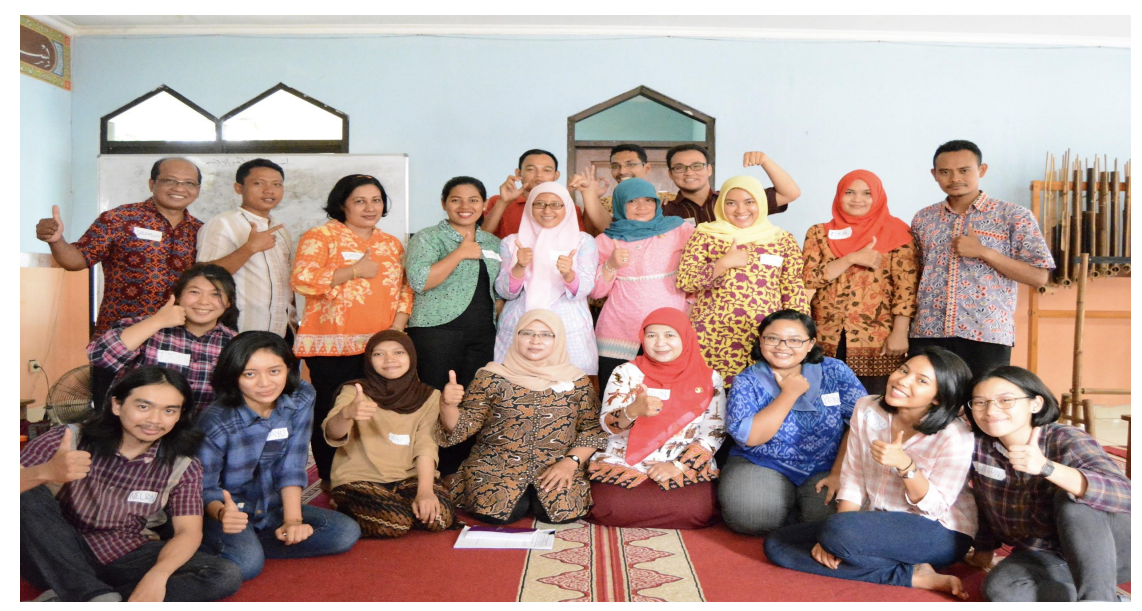

Fig. 3. Training on "The Golden Ways" on the third day with caregivers from PSAA Putra Utama 03 Ceger as Participants. 


\section{Conclusion}

The results of the training showed that training in the application of learned optimism and mindful parenting for PSAA Putra Utana 03 Ceger caregivers increased their knowledge about mindful parenting and how to be more optimistic. The training that had been carried out also increased the expectations of the caregivers of themselves to become better carers. After the training, caregivers also experienced increase in motivation to apply the material obtained during the training. The benefits of this training will be felt more optimally if the caregivers can continue to apply the knowledge they have acquired in their daily activities as caregivers of the orphanage. The caregivers of the orphanage can recall the materials given during the training and practice applying them using the workbook provided by the team.

\section{Suggestion}

Based on the experience of implementing learned optimism and mindful parenting in PSAA Putra Utama 03 Ceger to the caregivers, it is advised that future team who will continue such community service at PSAA Putra Utama 03 Ceger to pay attention to other problems that occur and can be intervened apart from the learning helplessness experienced by the caregivers.

In addition, it is also suggested for the activity participants, namely the caregivers of PSAA Putra Utama 03 Ceger to take an active part in applying the material they have obtained during the training in carrying out their duties as carers for the orphanage children. In addition, it is suggested that the caregivers support each other in applying the material that have been obtained during the training. The application of the material in the daily lives of caregivers at PSAA Putra Utama 03 Ceger can be a benefit for the optimal training, and the support provided by fellow carers is expected to make caregivers more enthusiastic and motivated in applying the material that has been given and making positive changes at PSAA Putra Main 03 Ceger.

The suggestion for PSAA Putra Utama 03 as an orphanage is to provide training programs for the caregivers on a regular basis, which aims to provide new knowledge in caring for the orphanage children to become better. The training program should also not only increase the knowledge of the caregivers, but also be able to restore or increase the motivation of the caregivers in fostering orphanage children. In addition to the training program, it is advised for the orphanage to hold activities that can be a means for caregivers to refresh and improve their solidarity as fellow caregivers. Another suggestion given is for the orphanage to provide 
counseling services for the caregivers, because it turns out that the caregivers at the orphanage have other burdens beyond their burden as caregivers at PSAA Putra Utama 03 Ceger.

Based on the results of the discussion regarding the limited time in carrying out the training, it is suggested that future teams to do training on the application of mindfulness to prepare sufficient time so that the training results can be more optimal. Methods such as case studies and roleplay are options if there is sufficient time in applying the material because they are in accordance with the learning model used by adults in the learning process. A suitable learning model to use is one that positions students as the main role in the learning process, where they can practice during the learning process because it is closely related to their lives (Kolb, 1984). In addition, the team should prepare a sufficient time span to measure the application of a new habit to the subject, namely 18-254 days.

\section{Acknowledgements}

The team would like to thank The Faculty of Psychology from UNIKA Atma Jaya which funded the training community service activity "The Golden Ways Training" and PSAA Putra Utama 03 Ceger orphanage and parties from the Social Service who have helped the team with the licensing and publication of this training. The team also would like to thank for the cooperation and high enthusiasm of the participants from the orphanage. Without cooperation, presence, and enthusiasm from the participants, this community service activity would have not completed as expected.

\section{References}

Arends, R. (2016). Learning to teach. Singapore: McGraw-Hill Education.

Aronson, E., Wilson, T. D., Akert, R. M., \& Sommers, S. (2012). Social psychology. New York: Pearson.

Baumeister, R. F., \& Leary, M. R. (1995). The Need to belong: Desire for interpersonal attachments as a fundamental human motivation. Psychological Bulletin, 117(3), 497529. Retrieved from Psychological Bulletin: doi:10.1037//0033-2909.117.3.497

Bogels, S. M., \& Restifo, K. (2014). Mindful parenting is: a guide for mental health practitioners. New York: Springer.

Carver, C. A., \& Scheier, M. F. (1999). Optimism . Psychology Review. US: Elsevier. 
Creswell, J. W. (2012). Educational research: planning, conducting, and evaluating quantitative and qualitative research. Boston: Pearson.

Johannes, L. M. (2010). The impact of parental attributions and characteristics on treatment outcome in multisystemic therapy for delinquent youth (Doctoral Dissertation, Ohio University)._https://search.proquest.com/openview/

Kolb, D. A. (1984). Experiential learning: Experience as the source of learning and development. New Jersey: Prentice-Hall.

Napitupulu, L., Nashori, H. F., \& Kurniawan, I. N. (2007). Pelatihan Adversity Intelligence Untuk Meningkatkan Kebermaknaan Hidup Remaja Panti Asuhan. Jurnal Psikologika, $13,43-56$.

Nock, M. K., \& Photos, V. (2006). Parent Motivation to Participate in Treatment: Assessment and Prediction of Subsequent Participation. Journal of Child and Family Studies, 15, 345-358.

Santrock, J. W. (2014). Adolescence (15th Ed). New York: NY: McGraw-Hill Education.

Senefeld, S., \& Perrin, P. C. (2014). Applying an ecological model to orphans and vulnerable children programming. Development in Practice, 24(1), 129-139. 